Available online at http://journal.stkip-andi-matappa.ac.id/index.php/histogram/index

Histogram : Jurnal Pendidikan Matematika 4(1), 2020, 190 - 202

\title{
PENGARUH TEKNIK BIMBINGAN BELAJAR GURU TERHADAP HASIL BELAJAR MATEMATIKA PADA SISWA
}

\author{
Musbaing $^{1^{*}}$, Muhammad Ilyas Ismail ${ }^{2}$ \\ ${ }^{1}$ Universitas Islam Makassar, ${ }^{2}$ UIN Alauddin \\ * Corresponding Author. Email: musbaing.dty@uim-makassar.ac.id \\ Received: 03 Januari 2020; Revised: 22 Januari 2020 ; Accepted: 30 Maret 2020
}

ABSTRAK

Tujuan penelitian ini yaitu (1) untuk mengetahui gambaran teknik bimbingan belajar guru. (2) untuk mengetahui gambaran hasil belajar matematika pada siswa, (3) untuk mengetahui pengaruh teknik bimbingan belajar guru terhadap hasil belajar matematika pada siswa. Penelitian ini merupakan penelitian eksperimen tipe The One Group Pretest-Posttest. Subjek penelitian ini adalah guru dan siswa kelas IV.A SDN Daya 1 Biringkanaya Makassar yang berjumlah 25 orang sebagai responden penelitian ini dilaksanakan pada semester ganjil 2019/2020. Instrumen penelitian yang digunakan dalam penelitian ini adalah tes, observasi, dan dokumentasi. Data yang diperoleh diolah dengan menggunakan analisis statistik deskriptif dan analisis statistik inferensial. Hasil penelitian ini menunjukkan bahwa: (1) Hasil belajar matematika siswa IV SDN Daya 1 sebelum perlakuan masuk dalam kategori kurang yaitu mean 50,60. Sedangkan hasil belajar setelah perlakuan berupa teknik bimbingan belajar menunjukan adanya peningkatan yaitu mean 80,20 termasuk kategori baik. (2) Data yang diperoleh dapat diketahui bahwa pelaksanaan teknik bimbingan belajar berpengaruh terhadap hasil belajar siswa di kelas IV SD Negeri Daya 1. Hal ini dapat dilihat dari nilai Sig.(2-tailed) < 0,05, diketahui bahwa ada perbedaan yang signifikan antara hasil belajar pretest siswa dengan hasil belajar posttest siswa.

Kata kunci : Teknik Bimbingan, Hasil Belajar Matematika.

\section{ABSTRACT}

The purpose of this research is (1) to find out the description of teacher tutoring techniques. (2) to find out the picture of mathematics learning results in students, (3) to find out the influence of teacher tutoring techniques on mathematics learning outcomes in students. This research is an experimental research type The One Group Pretest-Posttest. The subjects of this study were teachers and students of grade IV.A SDN Daya 1 Biringkanaya Makassar which numbered 25 people as respondents of this research conducted in the odd semester of 2019/2020. The research instruments used in this research are tests, observations, and documentation. The data obtained is processed using descriptive statistical analysis and inferential statistical analysis. The results of this study showed that: (1) The results of learning mathematics students iv SDN Daya 1 before treatment fall into the category of less than 50.60. While the results of learning after treatment in the form of tutoring techniques showed an increase of 80.20 mean including good categories. (2) The data obtained can be found that the implementation of tutoring techniques affects the learning outcomes of students in grade IV of SD Negeri Daya 1. This can be seen from the Sig value. (2tailed) $<0.05$, it is known that there is a significant difference between a student's pretest learning outcomes and a student's posttest learning outcomes.

Keywords: Guidance Techniques, Mathematics Learning Outcomes.

How to Cite: Musbaing., \& Ismail, M, I. (2020). Pengaruh Teknik Bimbingan Belajar Guru Terhadap Hasil Belajar Matematika Pada Siswa. Histogram: Jurnal Pendidikan Matematika, 4(1), 190 - 202, doi: http://dx.doi.org/10.31100/histogram.v4i1.533

Permalink/DOI: http://dx.doi.org/10.31100/histogram.v4i1.533

Copyright $($ C 2020, THE AUTHOR (S). This article distributed under the CC-BY-SA-license. 


\section{Histogram: Jurnal Pendidikan Matematika, 4 (1), 2020 - 191 Musbaing1, Muhammad Ilyas Ismail ${ }^{2}$}

\section{PENDAHULUAN}

Pendidikan merupakan sebuah program yang melibatkan sejumlah komponen yang bekerja sama dalam sebuah proses untuk mencapai tujuan yang diprogramkan dan merupakan aktifitas sadar dan sengaja diarahkan untuk mencapai suatu tujuan. (Purwanto). Hal ini sejalan dengan dengan pengertian pendidikan yang tertuang dalam Undang-Undang Republik Indonesia Nomor 20 tahun 2003 tentang Sistem Pendidikan Nasional pada Pasal 1 Ayat 1 yang berbunyi: "Pendidikan adalah usaha sadar dan terencana untuk mewujudkan suasana belajar dan proses pembelajaran agar peserta didik aktif mengembangkan potensinya untuk memiliki kekuatan spiritual keagamaan, pengendalian diri, kepribadian, kecerdasan, akhlak mulia, serta keterampilan yang diperlukan dirinya, masyarakat, bangsa dan negara". (Hasbullah, 2012)

Pendidikan nasional berfungsi mengembangkan kemampuan dan membentuk watak serta peradaban bangsa yang bermartabat dalam rangka mencerdaskan kehidupan bangsa, bertujuan untuk berkembangnya potensi anak didik agar menjadi manusia yang beriman dan bertaqwa kepada Tuhan Yang Maha Esa, berakhlak mulia, sehat, berilmu, cakap, kreatif, mandiri dan menjadi warga Negara yang demokratis serta bertanggung jawab. (Kurniadin \& Machali, 2009)

Kurikulum pendidikan dasar dan menengah wajib memuat 10 mata pelajaran yaitu Pendidikan Agama, Pendidikan Kewarganegaraan, Bahasa Indonesia, Matematika, Ilmu Pengetahuan Alam, Ilmu Pengetahuan Sosial, Seni Budaya dan Keterampilan, Pendidikan Jasmani, Olahraga dan Kesehatan, Muatan Lokal dan Pengembangan Diri. Di dalam peraturan Menteri Pendidikan Nasional ditegaskan bahwa mata pelajaran matematika merupakan ilmu universal yang mendasari perkembangan teknologi modern, mempunyai peranan penting dalam berbagai disiplin dan memajukan daya pikir manusia. Untuk menguasai dan menciptakan teknologi dimasa depan, diperlukan penguasaan matematika yang kuat sejak dini.

Berdasarkan wawancara peneliti dengan Kepala Sekolah SDN Daya 1 Kecamatan Biringkanaya Kota Makassar pada bulan September 2018, kurikulum yang digunakan di SD Negeri Daya 1 yaitu kurikulum 2013. Kurikulum 2013 merupakan kurikulum terintegrasi yang memungkinkan siswa baik secara individual maupun secara klasikal aktif menggali dan menemukan konsep dan prinsip-prinsip secara holistik bermakna dan otentik, melalui pertimbangan itu maka berbagai pandangan dan pendapat tentang pembelajaran terintegrasi, tapi semuanya menekankan pada penyampaian pembelajaran 


\section{Histogram: Jurnal Pendidikan Matematika, 4 (1), 2020 - 192 \\ Musbaing ${ }^{1}$, Muhammad Ilyas Ismail ${ }^{2}$}

yang bermakna dengan melibatkan siswa dalam proses pembelajaran, sehingga melalui pembelajaran terintegrasi ini siswa diharapkan memperoleh pengetahuan secara menyeluruh dengan cara mengaitkan satu pelajaran dengan pelajaran yang lain (Poerwati, Loeloek \& Amri, 2013)

Mata pelajaran matematika perlu diberikan kepada semua siswa mulai dari Sekolah Dasar untuk membekali siswa dengan kemampuan berpikir logis, analitis, sistematis, kritis dan kreatif serta kemampuan memperoleh, mengolah dan memanfaatkan informasi untuk bertahan hidup pada keadaan yang selalu berubah, tidak pasti dan kompetitif.

Keterampilan matematika tidak datang dengan sendirinya tetapi didasarkan atas pemahaman dan latihan yang cukup sehingga tidak mudah lupa terhadap konsep-konsep dan teorema-teorema yang telah dipelajari. Guru sebagai penggerak proses belajar mengajar diharapkan mampu memantau tingkat kesukaran yang dialami siswa, memberikan motivasi serta mampu mengarahkan dan mendorong kegiatan belajar.

Suatu pembelajaran dikatakan berhasil apabila siswa dapat memahami materi pelajaran yang disampaikan oleh guru dan mendapatkan hasil belajar yang diharapkan. Pembelajaran dikatakan berhasil dan berkualitas ditinjau dari segi proses apabila seluruhnya atau sebagian besar peserta didik terlibat secara aktif, baik fisik, mental maupun sosial dalam proses pembelajaran, disamping menunjukkan kegairahan belajar yang tinggi, semangat belajar yang besar dan percaya pada diri sendiri. Penerapan pembelajaran melalui kelompok kecil yang saling bekerja sama dan melibatkan siswa secara aktif diharapkan dapat meningkatkan pemahaman dan hasil belajar siswa khususnya pada mata pelajaran Matematika.

Keberhasilan pelaksanaan pembelajaran sangat bergantung pada sejauh mana pembelajaran itu didesain atau direncanakan. Sebaliknya, suatu pembelajaran yang tidak didesain secara sistematis tidak memperoleh hasil yang maksimal. Namun, tidak semua guru berkesempatan untuk melakukannya, mungkin karena banyaknya pekerjaan sampingan yang dilakukan selain menjalankan tugas sebagai guru atau mungkin menganggap bahwa pembelajaran yang hendak dilakukan sudah dapat dikuasai sehingga merasa tidak perlu didesain atau direncanakan lagi. Khusus pada mata pelajaran matematika, proses pembelajaran matematika perlu mendapatkan perhatian dan penanganan yang serius.

Namun, kenyataanya di dalam kelas seorang guru mengajar dalam pembelajaran, siswa tentunya memperhatikan dan mendengarkan apa yang sedang diuraikan oleh gurunya. Keadaan ini sungguh bertolak belakang dengan apa yang dialami pelajar ISSN: 2549-6700 (print), ISSN 2549-6719 (online) 


\section{Histogram: Jurnal Pendidikan Matematika, 4 (1), 2020 - 193 \\ Musbaing ${ }^{1}$, Muhammad Ilyas Ismail ${ }^{2}$}

sekarang. Mereka menyepelekan dan malas belajar yang sudah menjadi tanggung jawabnya sebagai seorang pelajar. Misalnya anak sedang membaca buku, pasti kita beranggapan bahwa dia belajar. Padahal belum tentu, Siapa tahu pandangan matanya diarahkan ke dalam buku tersebut, tetapi pikirannya menerawang ke arah lain yang menarik baginya. Hal seperti ini haruslah mendapatkan pengamatan yang mendalam.

Kemampuan siswa dalam menerima materi pelajaran matematika di sekolah memang berbeda-beda. Kemampuan siswa yang tergolong rendah, akan sangat mempengaruhi perolehan pengetahuannya. Padahal, perolehan pengetahuan berbanding lurus dengan perolehan nilai di sekolahnya. Masalah kemampuan siswa dalam menerima materi di sekolah ini dapat dilihat dari faktor internal, misalnya dari segi gizi yang kurang terpenuhi sehingga daya tahan tubuhnya terganggu, yang mengakibatkannya jadi kurang konsentrasi di sekolah. Selain itu, faktor psikologis siswa, misalnya kurang diperhatikan orang tua atau gurunya.

Berdasarkan observasi yang dilakukan pada bulan oktober 2018 di SDN Daya 1 Kecamatan Biringkanaya Kota Makassar. Dalam proses pembelajaran matematika yang dilaksanakan di kelas IV terdapat siswa yang aktif dalam proses pembelajaran dan seakan telah mengetahui lebih banyak dari temannya. Ketika peserta didik tersebut diberikan soal pertanyaan terkait materi ajar, maka peserta didik tersebut akan menjawab pertanyaan tersebut dengan jawaban yang sangat baik dan sistematis. Dalam proses pembelajaran juga ditemukan peserta didik yang jarang/hampir tidak pernah memberikan jawaban, pertanyaan ataupun masukan terhadap materi ajar. Namun, ketika diberikan tugas, siswa tersebut akan menjawab lebih cepat dan benar dibandingkan dengan siswa yang lain. Setelah proses pembelajaran tersebut, peneliti mencoba bertanya/melakukan observasi dalam bentuk wawancara kepada siswa tersebut, ternyata siswa yang bersangkutan mengikuti bimbingan belajar di luar sekolah yang dimana selangkah lebih maju materi ajar yang diajarkan di sekolah. Namun disisi lain, ada juga siswa yang tidak mengerti sama sekali pembelajaran yang diberikan oleh guru sehingga siswa tersebut apabila tidak dapat diatasi akan membuat siswa malas untuk belajar yang nantinya akan sangat berpengaruh terhadap hasil belajar siswa tersebut.

Salah satu inovasi yang menarik yang dapat dilakukan oleh guru yaitu dengan menerapkan teknik bimbingan belajar agar siswa dapat menyelesaikan permasalahan atau kesulitan yang dialaminya pada saat proses pembelajaran matematika sehingga dengan menerapkan teknik bimbingan belajar ini dapat mempengaruhi hasil belajar matematika siswa itu sendiri.

ISSN: 2549-6700 (print), ISSN 2549-6719 (online) 


\section{Histogram: Jurnal Pendidikan Matematika, 4 (1), 2020 - 194 Musbaing ${ }^{1}$, Muhammad Ilyas Ismail ${ }^{2}$}

Teknik Bimbingan belajar merupakan suatu jenis kegiatan pendidikan dan merupakan bentuk kegiatan dalam proses belajar yang dilakukan oleh seseorang yang telah memiliki kemampuan lebih dalam hal ini adalah guru untuk diberikan kepada siswa sebagai bantuan atau pertolongan dalam menghadapi masalah atau mengatasi kesulitan di dalam hal belajar. Yang meliputi yaitu: penyelesaian tugas-tugas dan latihan dari sejumlah bidang mata pelajaran, dan lain sebagainya.

Teknik bimbingan belajar mempunyai beberapa keunggulan, yakni memupuk tanggung jawab siswa dalam menilai kemampuannya sendiri dan menggunakan pengetahuan mereka secara efektif bagi dirinya, melatih siswa menjalani kehidupannya sekarang secara efektif dan menyiapkan dasar masa depannya sendiri, memupuk potensi siswa agar dapat berkembang secara optimal meliputi semua aspek pribadinya sebagai individu yang potensial. (Hamalik, 2010)

Dalam pembelajaran matematika, Teknik bimbingan belajar sangat baik untuk diterapkan dalam pembelajaran karena dengan adanya bantuan, bimbingan, dan perhatian dari guru akan membantu dan melatih siswa dalam menyelesaikan persoalan-persoalan matematika serta permasalahan atau kesulitan-kesulitan yang dialami oleh siswa dalam pembelajaran matematika tersebut sehingga akan berpengaruh pada hasil belajar matematika siswa.

Salah satu alasan peneliti menggunakan teknik bimbingan belajar adalah karena teknik bimbingan belajar efektif dalam mengatasi permasalahan atau kesulitan belajar siswa melalui bantuan, arahan dan bimbingan yang diberikan oleh guru tersebut. Peneliti memilih mata pelajaran matematika karena karena kajian matematika bersifat abstrak dan merupakan mata pelajaran yang paling digemari dan menjadi suatu kesenangan oleh sebahagian kecil peserta didik, tetapi bagi sebahagian besar peserta didik matematika merupakan mata pelajaran yang amat berat dan sulit, sehingga apabila masalah ini tidak dapat diatasi maka akan sangat berpengaruh terhadap hasil belajar siswa tersebut kedepannya, dikarenakan matematika tidak hanya dipelajari di sekolah dasar saja tetapi sampai perguruan tinggi.

Hasil penelitian terdahulu yang dilakukan menunjukkan bahwa teknik bimbingan belajar berpengaruh terhadap hasil belajar siswa. Penelitian yang dilakukan oleh Desti Kurnia Sarasweni, mahasiswi Universitas Negeri Yogyakarta tahun 2012 yang berjudul "Pengaruh Bimbingan Belajar terhadap Prestasi Belajar Matematika Siswa Kelas V SeKecamatan Kebasen. Hasil penelitian menunjukkan bahwa bimbingan belajar berpengaruh signifikan terhadap prestasi belajar matematika sebesar 55\% . Hal ini ISSN: 2549-6700 (print), ISSN 2549-6719 (online) 


\section{Histogram: Jurnal Pendidikan Matematika, 4 (1), 2020 - 195 \\ Musbaing ${ }^{1}$, Muhammad Ilyas Ismail ${ }^{2}$}

ditunjukkan dari perhitungan Analisis Regresi yang memperoleh $\mathrm{F}_{\text {hitung }}=5,49>\mathrm{F}_{\text {tabel }}=$ 3,89. (Sarasweni, Desti, 2012)

Penelitian ini diharapkan dapat memberikan bantuan atau sumbangan terhadap ilmu pengetahuan khususnya bidang ilmu pendidikan jurusan pendidikan guru sekolah dasar dan perkembangan mengenai pengaruh teknik bimbingan belajar guru terhadap hasil belajar matematika siswa dan semoga penelitian ini dapat digunakan sebagai bahan pertimbangan untuk guru dan kepala sekolah memperbaiki dan menyempurnakan proses belajar mengajar kedepannya dengan menggunakan teknik bimbingan belajar.

Berdasarkan uraian tersebut, maka penelitian tentang Pengaruh Teknik Bimbingan Belajar Guru Terhadap Hasil Belajar Matematika pada Siswa Kelas IV SDN Daya 1 Kecamatan Biringkanaya Kota Makassar sangat menarik untuk diteliti karena akan berimbas kepada hasil belajar matematika siswa dengan rumusan masalah penelitian adalah: (1) Bagaimana gambaran teknik bimbingan belajar guru di kelas IV SDN Daya 1?; (2) Bagaimana gambaran hasil belajar matematika pada siswa kelas IV SDN Daya 1?; (3) Apakah ada pengaruh teknik bimbingan belajar guru terhadap hasil belajar matematika pada siswa kelas IV SDN Daya 1 Kecamatan Biringkanaya Kota Makassar?

\section{METODE PENELITIAN}

\section{A. Jenis Penelitian dan Desain Penelitian}

Jenis penelitian yang digunakan dalam penelitian ini adalah jenis penelitian eksperimen yaitu The One Group Pretest-Posttest. Jenis penelitian ini digunakan untuk mengetahui apakah terdapat Pengaruh Teknik Bimbingan Belajar Guru terhadap Hasil Belajar Matematika pada Siswa Kelas IV SD Negeri Daya 1 Kecamatan Biringkanaya Kota Makassar. Adapun desain penelitian dapat digambarkan sebagai berikut:

Tabel 1. Desain Penelitian

\begin{tabular}{ccc}
\hline Pretest & Perlakuan & Posttest \\
\hline $\mathrm{O}_{1}$ & $\mathrm{X}$ & $\mathrm{O}_{2}$ \\
\hline
\end{tabular}

Keterangan :

$\mathrm{O}_{1} \quad$ : Hasil Pretest

X : Perlakuan, yakni pelaksanaan teknik bimbingan belajar

$\mathrm{O}_{2}$ : Hasil Posttest 


\section{Histogram: Jurnal Pendidikan Matematika, 4 (1), 2020 - 196 \\ Musbaing1, Muhammad Ilyas Ismail ${ }^{2}$}

\section{B. Variabel dan Desain Penelitian}

\section{Variabel Penelitian}

Pada Penelitian ini terdapat dua variabel yaitu variabel bebas dan variabel terikat. Teknik bimbingan belajar guru sebagai variabel bebas atau yang mempengaruhi dan hasil belajar matematika sebagai variabel tarikat atau yang dipengaruhi.

\section{Populasi Dan Sampel}

Populasi dalam penelitian ini adalah semua siswa SDN Daya 1. Sampel yang terpilih sebagai kelompok eksperimen adalah siswa kelas IV.A SDN Daya 1. Teknik pengambilan sampel yang digunakan dalam penelitian ini adalah purposive sampling, yaitu pengambilan sampel dengan tujuan penelitian. Pengambilan sampel berdasarkan pertimbangan dari wali kelas IV.A dan kepala sekolah.

\section{Instrumen Penelitian}

Instrumen yang digunakan dalam penelitian ini adalah: (1) Tes; (2) Lembar Observasi; (3) Dokumentasi

\section{E. Teknik dan Prosedur Pengumpulan Data \\ 1. Teknik pengumpulan data}

Teknik pengumpulan data yang digunakan dalam penelitian ini adalah sebagai berikut: (a) Observasi (pengamatan) digunakan untuk mengamatai teknik bimbingan belajar guru; (b) Tes digunakan untuk mengukur hasil belajar siswa; (c) Dokumentasi digunakan untuk melengkapi dan melihat dokumen guru beserta foto kegiatan siswa dan guru.

\section{Prosedur pengumpulan data}

Prosedur pengumpulan data yang digunakan dalam penelitian ini adalah sebagai:

(a) Perencanaan; (b) Pemberian pretes; (c) Pemberian perlakuan (treatment); (d) Pemberian posttest; (e) Analisis hasil

\section{F. Teknik Analisis Data}

\section{Analisis Deskriptif}

Analisis deskriptif digunakan untuk menganalisis data dengan cara mendeskripsikan atau menggambarkan data yang telah terkumpul sebagaimana adanya tanpa bermaksud membuat kesimpulan yang berlaku untuk umum atau generalisasi. Penyajian data analisis deskriptif melalui tabel, perhitungan modus, median, mean dan standar deviasi. 
Histogram: Jurnal Pendidikan Matematika, 4 (1), 2020 - 197

Musbaing ${ }^{1}$, Muhammad Ilyas Ismail ${ }^{2}$

Tabel 2. Kategorisasi Hasil Belajar

\begin{tabular}{cc}
\hline Skor & Kategori \\
\hline $85<\mathrm{x} \leq 100$ & Sangat Baik \\
\hline $69<\mathrm{x} \leq 85$ & Baik \\
\hline $54<\mathrm{x} \leq 69$ & Cukup \\
\hline $39<\mathrm{x} \leq 54$ & Kurang \\
\hline $0 \leq \mathrm{x} \leq 39$ & Sangat Kurang
\end{tabular}

(Sumber: Suyadi, Tahun: 2013)

Hasil belajar biasanya berbanding lurus dengan proses pembelajaran, proses pembelajaran yang dimaksudkan dalam penelitian ini adalah pelaksanaan teknik bimbingan belajar. Gambaran pelaksanaan teknik bimbingan belajar dikategorisasikan sebagai berikut.

Tabel 3. Kategorisasi Keterlaksanaan Teknik Bimbingan Belajar

\begin{tabular}{cc}
\hline Skor & Kategori \\
\hline $69<\mathrm{x} \leq 100$ & Baik \\
\hline $45<\mathrm{x} \leq 69$ & Cukup \\
\hline $0 \leq \mathrm{x} \leq 45$ & Kurang \\
\hline
\end{tabular}

(Sumber: Suyadi, Tahun: 2013)

\section{Analisis Inferensial}

\section{a. Uji Normalitas}

Uji normalitas dilakukan terhadap hasil belajar siswa. Pengujian ini dilakukan dengan bantuan program Statistical Package for Social Science (SPSS) versi 25 dengan uji Kolmogorov Smirnov Normality Test. Data normal jika sig> $\alpha$, untuk taraf signifikan ( $\alpha$ ) 5\%. Jika signifikansi lebih dari 0,05, maka data berdistribusi normal, begitupun sebaliknya.

\section{b. Uji Homogenitas}

Uji homogenitas dalam penelitian ini dilakukan dengan menggunakan sistem Statistical Pachage for Sosial Science (SPSS) versi 25.

\section{c. Uji Hipotesis}

Uji hipotesis diperoleh dari nilai posttest siswa. Uji hipotesis dalam penelitian ini menggunakan sistem Statistical Pachage for Sosial Science (SPSS) versi 25. Pengujian hipotesis menggunakan teknik pengujian Independent Sample. Independent Sample yaitu menguji perbedaan rata-rata dari nilai Pretest dengan Posttest siswa. Kriteria pengujian 


\section{Histogram: Jurnal Pendidikan Matematika, 4 (1), 2020 - 198 \\ Musbaing1, Muhammad Ilyas Ismail ${ }^{2}$}

jika nilai probabilitas lebih besar dari taraf nyata 0,05 maka $\mathrm{H}_{0}$ di terima dan $\mathrm{H}_{a}$ ditolak dan sebaliknya

\section{HASIL DAN PEMBAHASAN}

\section{A. Hasil Penelitian}

\section{a. Keterlaksanaan Teknik Bimbingan Belajar}

Data tentang keterlaksanaan teknik bimbingan belajar diperoleh melalui lembar observasi untuk guru dan siswa. Rekapitulasi skor keterlaksanaan teknik bimbingan belajar dilihat dari lembar observasi aktivitas guru pada setiap pertemuan disajikan sebagai berikut:

Tabel 4. Deskripsi keterlaksanaan teknik bimbingan belajar dilihat dari aktivitas guru.

\section{Pertemuan Pertemuan Pertemuan Pertemuan}

\begin{tabular}{|c|c|c|c|c|}
\hline & & II & III & IV \\
\hline Skor perolehan & $34 / 45$ & $35 / 45$ & $40 / 45$ & $41 / 45$ \\
\hline Persentase & $75 \%$ & $77 \%$ & $88,88 \%$ & $91,11 \%$ \\
\hline Kualifikasi & Baik & Baik & Baik & Baik \\
\hline
\end{tabular}

(Sumber: Data Primer, Tahun: 2019)

Berdasarkan tabel 4, indikator keterlaksanaan teknik bimbingan belajar diperoleh skor 34 pada pertemuan I dengan persentase keterlaksanaannya yaitu 75\% termasuk kategori baik, Skor 41 pada pertemuan IV dengan persentase keterlaksanaannya yaitu 91,11\% termasuk kategori baik. Hal ini menunjukkan bahwa pelaksanaan teknik bimbingan belajar terlaksana dengan baik.

Sedangkan data tentang keterlaksanaan teknik bimbingan belajar yang diperoleh melalui lembar observasi aktivitas siswa pada setiap pertemuan disajikan sebagai berikut:

Tabel 5. Deskripsi keterlaksanaan teknik bimbingan belajar dilihat dari aktivitas siswa.

\begin{tabular}{|c|c|c|c|c|}
\hline & $\begin{array}{c}\text { Pertemuan } \\
\text { I }\end{array}$ & $\begin{array}{c}\text { Pertemuan } \\
\text { II }\end{array}$ & $\begin{array}{c}\text { Pertemuan } \\
\text { III }\end{array}$ & $\begin{array}{c}\text { Pertemuan } \\
\text { IV }\end{array}$ \\
\hline Skor perolehan & $22 / 36$ & $23 / 36$ & $28 / 36$ & $29 / 36$ \\
\hline Persentase & $61,11 \%$ & $63,88 \%$ & $77,77 \%$ & $80,55 \%$ \\
\hline Kualifikasi & Cukup & Cukup & Baik & Baik \\
\hline
\end{tabular}

(Sumber: Data Primer, Tahun: 2019)

Berdasarkan tabel 5, indikator keterlaksanaan teknik bimbingan belajar diperoleh skor 22 pada pertemuan I dengan persentase keterlaksanaannya yaitu $61,11 \%$ termasuk kategori cukup, Skor 29 pada pertemuan IV dengan persentase keterlaksanaannya yaitu 


\section{Histogram: Jurnal Pendidikan Matematika, 4 (1), 2020 - 199}

Musbaing1, Muhammad Ilyas Ismail ${ }^{2}$

$80,55 \%$ termasuk kategori baik. Hal ini menunjukkan bahwa pelaksanaan teknik bimbingan belajar terlaksana dengan baik.

\section{b. Hasil Belajar}

\section{1) Deskripsi Data Pretest}

Setelah pelaksanaan kegiatan dalam penelitian, maka disajikan deskripsi data pretest yang merupakan hasil tes belajar siswa sebelum diberikan perlakuan berupa teknik bimbingan belajar sebagai berikut:

Tabel 6. Deskripsi Data Pretest

\begin{tabular}{lc}
\hline & Nilai Pretest \\
\hline Banyak Data & 25 \\
\hline Rata-rata & 50,60 \\
\hline Median & 45,00 \\
\hline Modus & 45 \\
\hline Standar Deviasi & 10,540 \\
\hline Rentang & 45 \\
\hline Minimun & 25 \\
\hline Maksimun & 70 \\
\hline Jumlah & 1265
\end{tabular}

(Sumber: Data Primer, Tahun: 2019)

Berdasarkan tabel 6, dapat dilihat bahwa mean atau rata-rata nilai hasil belajar pretest siswa 50,60 dari skor ideal 100 yang mungkin dicapai oleh siswa berada pada kategori kurang. Standar deviasi 10,540, hasil ini menunjukkan distribusi hasil belajar siswa pada saat pemberian pretest tersebar dari skor minimum 25 sampai dengan skor maksimun 70 dengan rentang 45 dan median 45,00.

\section{2) Deskripsi Data Posttest}

Setelah pelaksanaan teknik bimbingan belajar di kelas IV SD Negeri Daya 1, maka disajikan data posttest hasil belajar siswa untuk membandingkan dengan data pretest yang diperoleh sebelum penerapan teknik bimbingan belajar.

Tabel 7. Deskripsi Data Posttest

\begin{tabular}{lc}
\hline & Nilai Posttest \\
\hline Banyak Data & 25 \\
\hline Rata-rata & 80,20 \\
\hline Median & 80,00 \\
\hline Modus & 80 \\
\hline
\end{tabular}

ISSN: 2549-6700 (print), ISSN 2549-6719 (online) 
Histogram: Jurnal Pendidikan Matematika, 4 (1), 2020 - 200 Musbaing ${ }^{1}$ Muhammad Ilyas Ismail ${ }^{2}$

\begin{tabular}{lc}
\hline & Nilai Posttest \\
\hline Standar Deviasi & 6,690 \\
\hline Rentang & 25 \\
\hline Minimun & 70 \\
\hline Maksimun & 95 \\
\hline Jumlah & 2005 \\
\hline
\end{tabular}

(Sumber: Data Primer, Tahun: 2019)

Berdasarkan tabel 7, dapat dilihat bahwa mean atau rata-rata nilai hasil belajar posttest siswa 80,20 dari skor ideal 100 yang mungkin dicapai oleh siswa berada pada kategori baik. Standar deviasi 6,690 hasil ini menunjukkan distribusi hasil belajar postest tersebar dari skor minimum 70 sampai dengan skor maksimun 100 dengan rentang atau range 25. Modus yaitu 80 dan median 80,00 .

\section{c. Hasil Analisis Statistik Inferensial}

Sebelum melakukan uji hipotesis terlebih dahulu dilakukan uji asumsi yang terdiri dari uji normalitas dan uji homogenitas.

\section{1) Uji Normalitas}

Hasil uji normalitas menunjukkan bahwa data hasil pretest dan postest kelas eksperimen berdistribusi normal karena diperoleh nilai p-value pada masing-masing data yaitu $0,08>0,05$ dan $0,067>0,05$. Dengan demikian dapat disimpulkan bahwa data yang diperoleh berdistribusi normal.

\section{2) Uji Homogenitas}

Hasil uji homogenitas diperoleh nilai p-value yaitu $0,16>0,05$. Hal ini menunjukkan bahwa data pretest dan posttest homogen.

\section{3) Uji Hipotesis}

Berikut ini adalah hasil Independent Sample T-Test nilai pretest dan post-test.

Tabel 8. Hasil Independent Sample T-Test nilai Pretest dan Postest

\begin{tabular}{ccccc}
\hline Data & T & Df & Sig. .(2-tailed) & Keterangan \\
& & & & \\
\hline Pretest dan Posttest & -11.856 & 48 & 0,00 & $0,000<0,05$
\end{tabular}

\section{(Sumber: Data Primer, Tahun: 2019)}

Berdasarkan tabel 8, terlihat nilai Sig.(2-tailed) $<0,05$ diketahui bahwa ada perbedaan yang signifikan hasil belajar antara kelompok yang menggunakan teknik bimbingan belajar dengan kelompok yang tidak menggunakan teknik bimbingan belajar.

\section{B. Pembahasan}

ISSN: 2549-6700 (print), ISSN 2549-6719 (online) 


\section{Histogram: Jurnal Pendidikan Matematika, 4 (1), 2020 - 201 \\ Musbaing ${ }^{1}$, Muhammad Ilyas Ismail ${ }^{2}$}

\section{Gambaran Teknik Bimbingan Belajar Guru di SDN Daya 1 Kecamatan Biringkanaya Kota Makassar}

Proses pembelajaran dengan menggunakan teknik bimbingan belajar siswa dituntut untuk aktif dalam proses pembelajaran dimana siswa akan dilatih untuk dapat menyelesaikan soal pertanyaan yang diberikan oleh guru kemudian mempresentasikan cara penyelesaiannya didepan teman kelasnya. Selama proses pembelajaran siswa menjadi pusat kegiatan sedangkan guru hanya sebagai fasilitator yang membantu agar proses pembelajaran dapat berjalan dengan baik. Dengan teknik bimbingan belajar ini, siswa diajarkan untuk mandiri dalam menyelesaikan tugasnya tanpa meminta bantuan temannya atau tanpa bekerja sama dengan temannya untuk memupuk kemampuan siswa dalam menyelesaikan permasalahannya sendiri. Dalam proses pembelajaran, guru menjelaskan materi pembelajaran bangun datar dalam pelajaran matematika dengan mengaitkan benda-benda yang ada disekitarnya sehingga siswa lebih mudah memahami materi yang sedang dipelajarinya, dalam hal ini setiap siswa harus menjawab pertanyaan yang diberikan oleh guru dan jika ada siswa yang belum paham, guru akan memberikan bimbingan kepada siswa tersebut.

\section{Hasil Belajar Matematika Setelah Perlakuan (Treatment) Teknik Bimbingan Belajar}

Hasil belajar matematika setelah perlakuan (treatment) teknik bimbingan belajar dapat dilihat dari hasil belajar siswa yaitu nilai rata-rata (mean) hasil pre-test dan nilai rata-rata (mean) hasil post-test diketahui bahwa terdapat perbedaan yang signifikan dimana nilai rata-rata siswa sebelum perlakuan (Pretest) adalah 50,60 sedangkan nilai nilai rata-rata siswa setelah perlakuan (Posttest) adalah 80,20. Selanjutnya dilihat juga dari proses teknik bimbingan belajar dimana siswa lebih aktif dalam proses pembelajaran berlangsung. Jadi, dapat disimpulkan bahwa terdapat perbedaan yang rata-rata/signifikan hasil belajar sebelum perlakuan (pretest) dengan hasil belajar setelah perlakuan (posttest).

\section{Pengaruh Teknik Bimbingan Guru Terhadap Hasil Belajar Matematika pada}

\section{Siswa Kelas IV SDN Daya 1 Kecamatan Biringkanaya Kota Makassar}

Hasil analisis data membuktikan bahwa terdapat pengaruh teknik bimbingan belajar guru terhadap hasil belajar matematika pada siswa kelas IV, diperoleh nilai Sig.(2tailed $)<0,05$ sehingga $\mathrm{H}_{0}$ ditolak dan $\mathrm{H}_{\mathrm{a}}$ diterima, yang artinya terdapat pengaruh pengaruh teknik bimbingan belajar guru terhadap hasil belajar matematika pada siswa kelas IV SD Negeri Daya 1 Kecamatan Biringkanaya Kota Makassar 


\section{Histogram: Jurnal Pendidikan Matematika, 4 (1), 2020 - 202 \\ Musbaing ${ }^{1}$, Muhammad Ilyas Ismail ${ }^{2}$}

\section{KESIMPULAN DAN SARAN}

\section{A. Kesimpulan}

Berdasarkan hasil penelitian yang telah dilakukan dapat disimpulkan bahwa: (1) Gambaran pengaruh teknik bimbingan belajar guru terhadap hasil belajar matematika pada siswa kelas IV SD Negeri Daya 1, dilihat dari keaktifan siswa saat proses pembelajaran dan juga dilihat dari keterlaksanaan aspek yang diamati dilembar observasi pembelajaran dengan teknik bimbingan belajar memperoleh nilai $75 \%$ dan $91,11 \%$ yang termasuk dalam kategori baik; (2) Hasil belajar matematika setelah perlakuan (treatment) berada pada kategori baik. Hal tersebut dapat dilihat dari rata-rata (mean) pretest mengalami peningkatan yang ketika diberi posttest. Nilai rata-rata (mean) pretest yaitu 50,60 sedangkan nilai rata-rata (mean) posttest yaitu 80,20; (3) Pelaksanaan teknik bimbingan belajar berpengaruh terhadap hasil belajar siswa di kelas IV SD Negeri Daya 1. Hal ini dapat dilihat dari nilai Sig. $(2$-tailed $)<0,05$, diketahui bahwa ada perbedaan yang signifikan antara hasil belajar pretest siswa dengan hasil belajar posttest siswa.

\section{B. Saran}

Berdasarkan kesimpulan tersebut, maka dikemukakan beberapa saran sebagai berikut : (1) Guru hendaknya memberikan treatment kepada siswa berupa teknik bimbingan belajar yang digunakan pada mata pelajaran matematika di kelas IV SD Negeri Daya 1; (2) Untuk peneliti selanjutnya, agar dapat melakukan penelitian terhadap pokok bahasan atau mata pelajaran yang lainnya karena penelitian ini hanya mengambil satu pokok bahasan. Selain itu, penelitian ini hanya membatasi pada aspek kognitif saja. Maka dari itu diharapkan ada penelitian lebih lanjut mengenai teknik bimbingan belajar tersebut misalnya pada hasil belajar afektif ataupun psikomotor

\section{DAFTAR PUSTAKA}

Hamalik, O. (2010). Psikologi Belajar \& Mengajar. Bandung: Sinar Baru Algensindo.

Hasbullah. (2012). Dasar-dasar Ilmu Pendidikan. Jakarta: Rajawali Press.

Kurniadin, D., \& Machali, I. (2009). Psikologi Belajar. Bandung: Ar-Ruz Media.

Poerwati, Loeloek, E., \& Amri, S. (2013). Panduan Memahami Kurikulum 2013. Jakarta: Prestasi Pustaka Publisher.

Sarasweni, Desti, K. (2012). Pengaruh Bimbingan Belajar terhadap Prestasi Belajar Matematika Siswa Kelas V Se-Kecamatan Kebasen. Universitas Negeri Yogyakarta.

Suyadi. (2013). Strategi Pembelajaran Pendidikan Karakter. Bandung: Remaja Rosdakarya. 